\title{
Benefits of peritoneal ultrafiltration in HFpEF and HFrEF patients
}

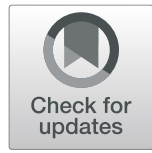

Leonie Grossekettler ${ }^{1 *}$, Bastian Schmack ${ }^{2}$, Carsten Brockmann ${ }^{3}$, Reinhard Wanninger ${ }^{4}$, Michael M. Kreusser ${ }^{1}$, Lutz Frankenstein ${ }^{1}$, Lars P. Kihm ${ }^{5}$, Martin Zeier ${ }^{5}$, Hugo A. Katus ${ }^{1}$, Vedat Schwenger ${ }^{5,6+}$ and Andrew Remppis ${ }^{7 \dagger}$

\begin{abstract}
Background: Peritoneal ultrafiltration (pUF) in refractory heart failure (HF) reduces the incidence of decompensation episodes, which is of particular significance as each episode incrementally adds to mortality. Nevertheless, there are insufficient data about which patient cohort benefits the most. The objective of this study was to compare pUF in HFrEF and HFpEF, focusing on functional status, hospitalizations, surrogate endpoints and mortality.
\end{abstract}

Methods: This study involves 143 patients, who could be classified as either HFpEF $(n=37,25.9 \%)$ or HFrEF ( $n=$ 106, 74.1\%) and who received pUF due to refractory HF.

Results: Baseline eGFR was similar in HFrEF $(23.1 \pm 10.6 \mathrm{mg} / \mathrm{dl})$ and HFpEF $(27.8 \pm 13.2 \mathrm{mg} / \mathrm{dl})$. Significant improvements in NYHA class were found in HFpEF $(3.19 \pm 0.61$ to $2.72 \pm 0.58, P<0.001)$ and HFrEF $(3.45 \pm 0.52$ to $2.71 \pm 0.72, P<0.001)$. CRP decreased in HFrEF $(19.4 \pm 17.6 \mathrm{mg} / \mathrm{l}$ to $13.7 \pm 21.4 \mathrm{mg} / \mathrm{l}, P=0.018)$ and HFpEF $(33.7 \pm$ $52.6 \mathrm{mg} / \mathrm{l}$ to $17.1 \pm 26.3 \mathrm{mg} / \mathrm{l}, P=0.004)$. Body weight was significantly reduced in HFrEF $(81.1 \pm 14.6 \mathrm{~kg}$ to $77.2 \pm$ $15.6 \mathrm{~kg}, P=0.003)$ and HFpEF $(86.9 \pm 15.8 \mathrm{~kg}$ to $83.1 \pm 15.9 \mathrm{~kg}, P=0.005)$. LVEF improved only in HFrEF $(25.9 \pm 6.82 \%$ to $30.4 \pm 12.2 \%, P=0.046)$. BCR decreased significantly in HFrEF and HFpEF $(55.7 \pm 21.9$ to $34.3 \pm 17.9 P>0.001$ and $50.5 \pm 68.9$ to $37.6 \pm 21.9, P=0.006$ ). Number of hospitalization episodes as well as number of hospitalization days decreased significantly only in HFpEF (total number $2.88 \pm 1.62$ to $1.25 \pm 1.45, P<0.001$, days $40.4 \pm 31.7$ to $18.3 \pm$ 22.5 days, $P=0.005)$.

Conclusions: pUF offers various benefits in HFpEF and HFrEF, but there are also substantial differences. In particular, hospitalization rates were found to be significantly reduced in HFpEF patients, indicating a greater medical and economical advantage. However, LVEF was only found to be improved in HFrEF patients. While pUF can now be regarded as an option to supplement classical HF therapy, further studies are desirable to obtain specifications about pUF in HFpEF, HFmEF and HFrEF patients.

Keywords: Heart failure, HFpEF, HFrEF, Cardiorenal syndrome, Peritoneal dialysis, Ultrafiltration

\footnotetext{
* Correspondence: leonie.grossekettler@med.uni-heidelberg.de

${ }^{\dagger}$ Vedat Schwenger and Andrew Remppis contributed equally to this work.

'Department of Internal Medicine III, Cardiology, Angiology and

Pulmonology, University Hospital of Heidelberg, Im Neuenheimer Feld 410,

69120 Heidelberg, Germany

Full list of author information is available at the end of the article
}

(c) The Author(s). 2020 Open Access This article is licensed under a Creative Commons Attribution 4.0 International License, which permits use, sharing, adaptation, distribution and reproduction in any medium or format, as long as you give appropriate credit to the original author(s) and the source, provide a link to the Creative Commons licence, and indicate if changes were made. The images or other third party material in this article are included in the article's Creative Commons licence, unless indicated otherwise in a credit line to the material. If material is not included in the article's Creative Commons licence and your intended use is not permitted by statutory regulation or exceeds the permitted use, you will need to obtain permission directly from the copyright holder. To view a copy of this licence, visit http://creativecommons.org/licenses/by/4.0/ The Creative Commons Public Domain Dedication waiver (http://creativecommons.org/publicdomain/zero/1.0/) applies to the data made available in this article, unless otherwise stated in a credit line to the data. 


\section{Background}

The global prevalence of heart failure (HF) is increasing, due to ageing populations, insufficiently controlled cardiovascular risk factors as well as prolonged survival in consequence of evidence-based treatments [1]. The rising frequency of HF leads to growing problems - medically, economically and ethically.

Especially in patients over 60 years, HF is the main reason for hospitalization [2]. In the US, 30 day all cause readmission rate is 19\%. In Europe 1-year rehospitalization rates run up to $44 \%$, while $32 \%$ of outpatients experience a first hospitalization [3].

HF can be classified as heart failure with reduced left ventricular ejection fraction (HFrEF) (LVEF < 40\%), heart failure with preserved ejection fraction (HFpEF) and recently heart failure with mid-range ejection fraction (HFmEF, LVEF 40-55\%). Prognosis of HF is known to be rather poor: Overall 1-year mortality is $8.8 \%$ in HFrEF and 6.3\% in HFpEF [4]. HF index admission mortality is around $10 \%$ with a post-discharge 30 -day and 1year mortality of 6.5 and $30 \%$, respectively [5]. It has to be noted, that HFrEF therapy is based on a wide range of studies yielding a sound basis for an evidence-based medical approach $[6,7]$, while HFpEF therapy is largely devoid of any scientific evidence.

The cardiorenal syndrome is an overarching pathophysiology in HF, irrespective of EF [1, 8-11]. It is associated with worse outcome with more than $40 \%$ of allcause mortality being attributable to this co-morbid situation and which represents the main driver for recurrent hospitalizations [12-15].

Due to critical changes in intraglomerular filtration pressures, renal venous congestion and arterial underfilling both lead to "excretory renal insufficiency" with an inadequate volume control triggering recurring hydropic decompensations [10, 14-21]. Importantly, neurohormonal imbalance in HF contributes to these hydropic decompensations by hindering adequate excretion of sodium and water. Therefore, loop diuretics are recommended in current guidelines as first line therapy in patients with acute and chronic decompensated HF (ESC, AHA, ACCF) [6, 7]. Main focus is symptom relief and co-morbidity therapy, suggesting UF or haemofiltration as possible treatment option but fail to specify any details [22]. However, until now no evidence has emerged on superiority of extracorporeal UF compared to diuretic strategies [23-28].

Peritoneal UF (pUF) in patients with in end stage HF and refractory congestion can offer an additional treatment option [29] and is associated with improved New York Heart Association (NYHA) classification and reduced hospitalizations, as we could demonstrate in our previous study [30]. Although frequently used and suggested by the German Societies of Cardiology and
Nephrology for treatment of patients with chronic refractory cardiorenal syndrome [31], no data are available whether outcome in HF patients treated with pUF differs with respect to the underlying cardiac pathophysiology and which patient cohort would clinically benefit the most from pUF.

Therefore, the aim of this study was to determine possible advantages and disadvantages of pUF treatment in HFpEF versus HFrEF (according to ESC 2012) [1].

\section{Methods}

This is a substudy of our prospective observational multicentre study, based on the national registry data of the German Society of Nephrology (DGfN), to evaluate the efficacy of pUF in patients with refractory HF, this time focusing on HFpEF and HFrEF. One hundred forty-three patients with symptomatic end-stage CHF, classified as either HFpEF or HFrEF, were enrolled in ambulatory pUF therapy after interdisciplinary assessment. Enrolment period took place between January 2010 and December 2014. The inclusion criteria are listed below:

a) Individually optimized pharmacological therapy according to the recommendation of the European Society of Cardiology (ESC) [1]

b) Diuretic resistance defined as refractory hypervolemia despite optimal sequential diuretic therapy (loop diuretics, thiazides and, if possible, mineralocorticoid receptor antagonists (MRA) as recommended by national authorities $[1,28]$

c) Device therapy as indicated by current guidelines [1]

d) Recurrent hospitalizations due to cardiac decompensation, at least $2 \mathrm{x}$ within the last 6 months

e) Patients not eligible for heart transplantation

Exclusion criteria for this study were defined as standard contraindications for pUF as well as inotropic support [28]. The registry did not include any acute peritoneal dialysis (PD) initiations on ICU. The Modification of Diet in Renal Disease (MDRD) equation was used to calculate renal function, as estimated by glomerular filtration rate (eGFR).

Before confirming the indication for pUF, patients received optimization of conservative medical HF therapy and echocardiography to determine LVEF. It was sought to formerly exclude diagnosis of specific renal pathologies e.g. glomerulonephritis.

Patients were carefully instructed after implantation of a peritoneal dialysis catheter. pUF modalities were continuous ambulatory PD (CAPD), automated PD (APD) or intermittent PD (IPD). Study visits were scheduled at initiation of pUF, at 3 and 6 months, and subsequently 
Table 1 Baseline patient characteristics. Medical and demographic data. Data are presented as mean \pm standard deviation (SD) or number

\begin{tabular}{|c|c|c|}
\hline & $\mathrm{n}$ & (Percent) \\
\hline & 143 & $(100 \%)$ \\
\hline \multicolumn{3}{|l|}{ Characteristic of HF } \\
\hline HF with reduced EF $(<40 \%)$ & 106 & $(74.1 \%)$ \\
\hline HF with preserved EF (> 40\%) & 37 & $(25.9 \%)$ \\
\hline \multicolumn{3}{|l|}{ Sex (male: female) } \\
\hline Total & m 119: f 24 & (83.2\%: 16.8\%) \\
\hline $\mathrm{HFrEF}{ }^{\mathrm{b}}$ & m 91: f 15 & (63.6\%: 10.5\%) \\
\hline $\mathrm{HFpEF}^{c}$ & m 28: f 9 & (19.5\%: 6.29\%) \\
\hline
\end{tabular}

\section{Etiology of $\mathrm{CHF}^{\mathrm{a}}$}

HFrEF ${ }^{\mathrm{b}}$
Ischemic cardiomyopathy
Dilated cardiomyopathy
Pulmonary hypertension and right ventricular dysfunction
Hypertensive heart disease
Congenital heart defect
Not specified
HFpEF
Ischemic cardiomyopathy
Dilated cardiomyopathy
Pulmonary hypertension and right ventricular dysfunction
Pericarditis constrictiva
Hypertensive heart disease
Congenital heart defect
Not specified

\section{Valvular heart disease}

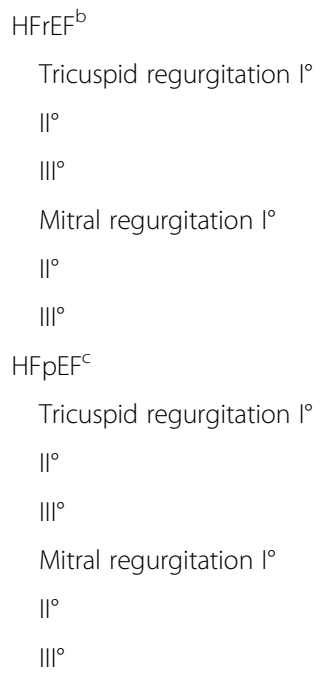

$\mathrm{HFpEF}^{\mathrm{C}}$

Tricuspid regurgitation $l^{\circ}$

\section{Medication}

HFrEF $^{b}$ 
Table 1 Baseline patient characteristics. Medical and demographic data. Data are presented as mean \pm standard deviation (SD) or number (Continued)

\begin{tabular}{|c|c|c|}
\hline & $n$ & (Percent) \\
\hline Spironolacton & 40 & $(28.0 \%)$ \\
\hline \multicolumn{3}{|l|}{$\mathrm{HFpEF}{ }^{\mathrm{C}}$} \\
\hline Angiotensin Converting Enzyme Inhibitors / Angiotensin Receptor Blockers & 20 & $(14.0 \%)$ \\
\hline Beta Blockers & 21 & $(14.7 \%)$ \\
\hline Spironolacton & 13 & (9.09\%) \\
\hline Erythropoietin & 8 & $(5.59 \%)$ \\
\hline \multicolumn{3}{|l|}{ pUF $^{d}$ regime at beginning } \\
\hline \multicolumn{3}{|l|}{$\mathrm{HFrEF}^{\mathrm{b}}$} \\
\hline $\mathrm{APD}^{\mathrm{e}}$ & 36 & $(25.2 \%)$ \\
\hline CAPD $^{f}$ & 54 & $(37.8 \%)$ \\
\hline $\mathrm{IPD}^{\mathrm{g}}$ & 3 & $(2.10 \%)$ \\
\hline \multicolumn{3}{|l|}{ HFpEFc } \\
\hline$A P D^{e}$ & 14 & (9.79\%) \\
\hline CAPD $^{f}$ & 18 & $(12.6 \%)$ \\
\hline $\mathrm{IPD}^{\mathrm{g}}$ & 1 & $(0.70 \%)$ \\
\hline \multicolumn{3}{|l|}{ Haemodialysis prior to pUF $^{d}$} \\
\hline $\mathrm{HFrEF}{ }^{\mathrm{b}}$ & 11 & $(7.69 \%)$ \\
\hline $\mathrm{HFpEF}{ }^{c}$ & 5 & (3.50\%) \\
\hline
\end{tabular}

${ }^{\mathrm{a}} \mathrm{CHF}$ (congestive heart failure)

${ }^{b}$ HFrEF (heart failure with reduced ejection fraction)

${ }^{c} \mathrm{HFpEF}$ (heart failure with preserved ejection fraction)

d pUF (peritoneal ultrafiltration)

APD (automatic peritoneal dialysis)

${ }^{f}$ CAPD (continuous ambulatory peritoneal dialysis)

${ }^{g}$ IPD (intermittent peritoneal dialysis)

in 6 months periods. Primary end-point of the study was defined as all-cause hospitalizations.

All patients provided written informed consent prior to study enrolment. The study was approved by the Ethics Committee of the Medical Faculty of Heidelberg (reference number S-106/2011).

Statistical analysis were performed using IBM SPSS Statistics 24 and Microsoft Excel 2011, including Kolmogorov-Smirnov test, Wilcoxon signed-rank test or Students t-test for paired variables, Levene's test, Pearson's correlation, as well as Kaplan-Meier estimator and log-rank test (level of significance $\alpha=5 \%$ ).

\section{Results}

The study population included 143 patients with a median follow-up time of 302 days (range 9 to 2357). According to ESC 2012 [1], 106 patients were classified as HFrEF $(\mathrm{EF}<40 \%)(74.1 \%)$ and 37 patients were classified as HFpEF (EF > 40\%) (25.9\%). Patient characteristics and treatment modalities of both study groups are demonstrated in Table 1.

Pre-pUF, $51 \mathrm{HFrEF}$ patients (47.7\%) and $20 \mathrm{HFpEF}$ patients (54.1\%) received cardiac catheterization. In 57 HFrEF patients $(53.3 \%)$ and 9 HFpEF patients $(23.3 \%)$ an implantable cardioverter-defibrillator (ICD) was implanted. $11 \mathrm{HFrEF}$ patients (10.3\%) and $5 \mathrm{HFpEF}$ patients $(13.5 \%)$ required precursory intermittent haemodialysis before starting pUF, main reasons were acute hypervolemia or hyperkalaemia (in HFrEF mean duration of haemodialysis $11.9 \pm 1.96 \mathrm{~h}$ per week, or 3 times a week with average period of $3.97 \pm 0.65 \mathrm{~h}$, respectively; average blood flow $235.0 \pm 24.2 \mathrm{ml} / \mathrm{min}$, in HFpEF mean duration of haemodialysis $14.8 \pm 6.38 \mathrm{~h}$ per week, or 3 times a week with average period of $4.93 \pm 2.13 \mathrm{~h}$, respectively; average blood flow $293.3 \pm 11.6 \mathrm{ml} / \mathrm{min}$ ).

Treatment modality at the beginning of pUF was mainly CAPD in both groups (HFrEF 50.9\% and HFpEF 48.6\%). Average $\mathrm{Kt} / \mathrm{V}$ was $2.62 \pm 1.81$ in HFrEF and $2.20 \pm 0.89$ in HFpEF. 10 HFrEF (9.35\%) and 3 HFpEF patients (8.12\%) required intermittent haemodialysis at different time points after beginning of pUF. 25 HFrEF patients (23.6\%) and 11 HFpEF patients $(29.7 \%)$ received Icodextrin.

Laboratory results are demonstrated in Table 2 . The mean within-person change of NTproBNP was more pronounced in HFpEF (-379 ng/l, relative change $-7 \%$ ) than in HFrEF (absolute $-2133 \mathrm{ng} / \mathrm{l}$, relative change $-0.5 \%$ ) patients.

Creatinine increased significantly in HFpEF group $(2.65 \pm 1.29 \mathrm{mg} / \mathrm{dl}$ to $4.00 \pm 2.15 \mathrm{mg} / \mathrm{dl}, P=0.008)$ while 
Table 2 Laboratory variables at baseline and after beginning of pUF ${ }^{a}$

\begin{tabular}{|c|c|c|c|c|c|c|c|c|c|}
\hline \multirow{2}{*}{\multicolumn{2}{|c|}{ Pre-pUF }} & \multicolumn{8}{|l|}{ Post-pUF ${ }^{a}$} \\
\hline & & 3 months & $P$ & 6 months & $P$ & 12 months & $P$ & Last follow- up & $P$ \\
\hline \multicolumn{10}{|c|}{ hs TNT ${ }^{d}(p g / m l)$} \\
\hline $\mathrm{HFrEF}^{\mathrm{b}}$ & $108.0 \pm 233.1$ & $77.5 \pm 58.7$ & 0.189 & $136.3 \pm 184.7$ & 0.608 & $105.6 \pm 79.5$ & 0.046 & $107.3 \pm 39.0$ & 0.949 \\
\hline HFpEF & $152.0 \pm 236.5$ & $124.3 \pm 12.4$ & 0.586 & $150.0 \pm 198.0$ & 0.410 & $123.3 \pm 57.5$ & 0.848 & $177.5 \pm 101.4$ & 0.665 \\
\hline \multicolumn{10}{|c|}{ NT proBNP (pg/ml) } \\
\hline $\mathrm{HFrEF}^{\mathrm{b}}$ & $5220.1 \pm 4438.4$ & $4944.7 \pm 10,351.8$ & 0.404 & $5242.6 \pm 8465.3$ & 0.542 & $3539.6 \pm 5776.2$ & 0.309 & $6650.0 \pm 11,197.5$ & 0.148 \\
\hline HFpEF & $2630.3 \pm 2029.7$ & $1980.0 \pm 2309.6$ & 0.323 & $2033.9 \pm 2701.2$ & 0.645 & $2059.0 \pm 3218.6$ & 0.937 & $2407.0 \pm 5296.6$ & 0.495 \\
\hline \multicolumn{10}{|c|}{ Albumin (g/l) } \\
\hline HFrEF ${ }^{b}$ & $38.6 \pm 5.59$ & $37.8 \pm 5.76$ & 0.200 & $38.0 \pm 7.65$ & 0.140 & $38.9 \pm 4.89$ & 0.509 & $37.9 \pm 7.43$ & 0.166 \\
\hline HFpEF & $38.0 \pm 6.64$ & $35.5 \pm 7.73$ & 0.147 & $36.4 \pm 3.91$ & 0.884 & $39.8 \pm 3.27$ & 0.309 & $35.4 \pm 5.54$ & 0.187 \\
\hline \multicolumn{10}{|c|}{ Creatinine (mg/dl) } \\
\hline $\mathrm{HFrEF}^{\mathrm{b}}$ & $3.19 \pm 3.12$ & $3.14 \pm 2.62$ & 0.717 & $3.49 \pm 2.67$ & 0.959 & $3.30 \pm 2.82$ & 0.133 & $3.90 \pm 2.98$ & 0.090 \\
\hline $\mathrm{HFpEF}^{c}$ & $2.65 \pm 1.29$ & $2.96 \pm 1.62$ & 0.220 & $3.32 \pm 1.97$ & 0.008 & $3.77 \pm 2.29$ & 0.018 & $4.00 \pm 2.15$ & 0.008 \\
\hline \multicolumn{10}{|c|}{$\operatorname{MDRD}^{\mathrm{e}}$ eGFR $\left(\mathrm{ml} / \mathrm{min} / 1.73 \mathrm{~m}^{2}\right)$} \\
\hline $\mathrm{HFrEF}^{\mathrm{b}}$ & $23.1 \pm 10.6$ & $28.4 \pm 18.3$ & 0.240 & $25.9 \pm 14.8$ & 0.351 & $26.3 \pm 14.6$ & 0.620 & $23.3 \pm 19.8$ & 0.841 \\
\hline $\mathrm{HFpEF}^{c}$ & $27.8 \pm 13.2$ & $26.5 \pm 15.1$ & 0.628 & $27.4 \pm 17.4$ & 0.530 & $23.3 \pm 15.2$ & 0.094 & $19.5 \pm 15.4$ & 0.042 \\
\hline \multicolumn{10}{|c|}{ BUN (mg/dl) } \\
\hline $\mathrm{HFrEF}^{\mathrm{b}}$ & $145.4 \pm 68.0$ & $109.2 \pm 84.7$ & $<0.001$ & $103.0 \pm 42.5$ & $<0.001$ & $94.1 \pm 37.4$ & $<0.001$ & $102.9 \pm 42.1$ & $<0.001$ \\
\hline $\mathrm{HFpEF} F^{c}$ & $153.5 \pm 69.2$ & $94.6 \pm 32.5$ & 0.011 & $101.4 \pm 39.8$ & 0.015 & $105.6 \pm 45.4$ & 0.070 & $117.3 \pm 48.8$ & 0.117 \\
\hline \multicolumn{10}{|l|}{ CRP (mg/l) } \\
\hline $\mathrm{HFrEF}^{\mathrm{b}}$ & $37.9 \pm 59.0$ & $14.4 \pm 29.4$ & 0.002 & $9.90 \pm 12.5$ & 0.002 & $8.67 \pm 8.36$ & 0.011 & $17.3 \pm 27.6$ & 0.009 \\
\hline $\mathrm{HFpEF}^{c}$ & $19.4 \pm 17.6$ & $6.56 \pm 7.93$ & 0.067 & $6.83 \pm 8.16$ & 0.069 & $13.3 \pm 26.1$ & 0.028 & $13.7 \pm 21.4$ & 0.019 \\
\hline \multicolumn{10}{|c|}{ Sodium (mmol/l) } \\
\hline $\mathrm{HFrEF}^{\mathrm{b}}$ & $136.2 \pm 5.07$ & $137.9 \pm 4.88$ & 0.025 & $137.1 \pm 4.84$ & 0.127 & $138.2 \pm 4.04$ & 0.055 & $136.6 \pm 5.31$ & 0.992 \\
\hline $\mathrm{HFpEF}^{c}$ & $137.2 \pm 3.85$ & $137.4 \pm 10.1$ & 0.602 & $138.3 \pm 5.30$ & 0.821 & $136.9 \pm 5.72$ & 0.336 & $137.1 \pm 6.47$ & 0.089 \\
\hline \multicolumn{10}{|c|}{ Potassium (mmol/l) } \\
\hline $\mathrm{HFrEF}^{\mathrm{b}}$ & $4.32 \pm 0.74$ & $4.22 \pm 0.68$ & 0.035 & $4.19 \pm 0.60$ & 0.013 & $4.26 \pm 0.54$ & 0.213 & $4.29 \pm 0.85$ & 0.217 \\
\hline $\mathrm{HFpEF}^{c}$ & $4.25 \pm 0.68$ & $4.14 \pm 0.64$ & 0.287 & $4.50 \pm 0.56$ & 0.107 & $4.02 \pm 0.50$ & 0.340 & $4.36 \pm 0.62$ & 0.756 \\
\hline \multicolumn{10}{|c|}{ Phosphate (mmol/l) } \\
\hline $\mathrm{HFrEF}^{\mathrm{b}}$ & $1.47 \pm 0.51$ & $1.47 \pm 0.65$ & 0.984 & $1.59 \pm 0.78$ & 0.771 & $1.61 \pm 0.97$ & 0.315 & $1.67 \pm 1.16$ & 0.146 \\
\hline $\mathrm{HFpEF}^{c}$ & $1.86 \pm 1.98$ & $1.72 \pm 1.14$ & 0.276 & $1.54 \pm 0.51$ & 0.428 & $1.37 \pm 0.30$ & 0.470 & $1.86 \pm 1.56$ & 0.388 \\
\hline \multicolumn{10}{|c|}{ Haemoglobin (mg/dl) } \\
\hline $\mathrm{HFrEF}^{\mathrm{b}}$ & $11.3 \pm 1.74$ & $11.9 \pm 1.71$ & 0.024 & $11.7 \pm 2.20$ & 0.030 & $12.6 \pm 1.79$ & $<0.001$ & $11.6 \pm 2.09$ & 0.614 \\
\hline $\mathrm{HFpEF}^{c}$ & $10.8 \pm 1.68$ & $11.7 \pm 2.12$ & 0.038 & $11.9 \pm 2.29$ & 0.014 & $11.9 \pm 1.87$ & 0.025 & $11.2 \pm 2.40$ & 0.105 \\
\hline
\end{tabular}

Data are presented as mean \pm SD

${ }^{a}$ pUF (peritoneal ultrafiltration)

${ }^{\mathrm{b}} \mathrm{HFrEF}$ (heart failure with reduced ejection fraction)

CHFrEF (heart failure with preserved ejection fraction)

dhsTNT (high sensitive troponin)

${ }^{\mathrm{e} M D R D}$ (modification of diet in renal disease)

${ }^{\mathrm{f}} \mathrm{eGFR}$ (estimated glomerular filtration rate)

MDRD revealed a slight decrease $(27.8 \pm 13.2 \mathrm{ml} / \mathrm{min} /$ $1.73 \mathrm{~m}^{2}$ to $\left.19.5 \pm 15.4 \mathrm{ml} / \mathrm{min} / 1.73 \mathrm{~m}^{2}, P=0.0042\right)$. BUN declined more sustained in HFrEF patients (HFrEF $145.4 \pm 68.0 \mathrm{mg} / \mathrm{dl}$ to $102.9 \pm 42.1 \mathrm{mg} / \mathrm{dl}, \quad P<0.001)$. BUN/creatinine ratio (BCR) declined significantly in both groups (HFrEF $55.7 \pm 21.9$ to $34.3 \pm 17.9 P>0.001$ and HFpEF $(50.5 \pm 68.9$ to $37.6 \pm 21.9, P=0.006)$.

CRP improved in HFrEF and HFpEF with pUF treatment. Albumin remained unchanged over all.

Follow-up results of clinical variables after beginning of pUF are shown in Table 3. Comparing HFpEF and 
Table 3 Clinical variables at baseline and after beginning of pUF ${ }^{a}$. Median, standard deviation and students t-test for paired variables. Mean and Wilcoxon signed-rank text for not normally contributed paired variables

\begin{tabular}{|c|c|c|c|c|c|c|c|c|c|}
\hline & \multirow[t]{2}{*}{ Pre-pUF ${ }^{a}$} & \multicolumn{8}{|l|}{ Post-puF ${ }^{a}$} \\
\hline & & 3 months & $P$ & 6 months & $P$ & 12 months & $P$ & Last follow up & $P$ \\
\hline \multicolumn{10}{|l|}{ NYHA $^{\text {d }}$} \\
\hline HFrEF ${ }^{b}$ & $3.45 \pm 0.52$ & $2.80 \pm 0.50$ & $<0.001$ & $2.79 \pm 0.71$ & 0.001 & $2.53 \pm 0.75$ & $<0.001$ & $2.71 \pm 0.72$ & $<0.001$ \\
\hline $\mathrm{HFpEF}^{\mathrm{C}}$ & $3.19 \pm 0.61$ & $2.82 \pm 0.56$ & 0.002 & $2.44 \pm 0.68$ & 0.028 & $2.63 \pm 0.69$ & 0.045 & $2.72 \pm 0.58$ & $<0.001$ \\
\hline \multicolumn{10}{|c|}{ Systolic BP $(\mathrm{mmHg})$} \\
\hline $\mathrm{HFrEF}^{\mathrm{b}}$ & $108.4 \pm 18.7$ & $111.2 \pm 18.9$ & 0.674 & $111.6 \pm 18.9$ & 0.846 & $117.0 \pm 23.1$ & 0.875 & $108.2 \pm 23.2$ & 0.284 \\
\hline $\mathrm{HFpEF}^{c}$ & $115.9 \pm 20.7$ & $120.1 \pm 17.1$ & 0.703 & $114.9 \pm 20.6$ & 0.680 & $110.1 \pm 19.6$ & 0.354 & $114.3 \pm 22.8$ & 0.799 \\
\hline \multicolumn{10}{|c|}{ Diastolic $\mathbf{B P}^{\mathrm{e}}(\mathrm{mmHg})$} \\
\hline $\mathrm{HFrEF}^{\mathrm{b}}$ & $68.4 \pm 12.6$ & $65.8 \pm 11.7$ & 0.001 & $67.2 \pm 13.3$ & 0.097 & $69.8 \pm 17.0$ & 0.270 & $66.3 \pm 14.2$ & 0.010 \\
\hline $\mathrm{HFpEF}^{c}$ & $67.1 \pm 10.1$ & $64.7 \pm 7.18$ & 0.542 & $66.5 \pm 10.0$ & 0.639 & $64.2 \pm 12.3$ & 0.752 & $64.0 \pm 11.1$ & 0.533 \\
\hline \multicolumn{10}{|l|}{$\mathrm{EF}^{\mathrm{f}}(\%)$} \\
\hline $\mathrm{HFrEF}^{\mathrm{b}}$ & $25.9 \pm 6.82$ & $29.0 \pm 8.30$ & 0.081 & $29.6 \pm 8.75$ & 0.154 & $31.1 \pm 12.8$ & 0.281 & $30.4 \pm 12.2$ & 0.046 \\
\hline $\mathrm{HFpEF}^{c}$ & $51.3 \pm 7.77$ & $48.2 \pm 5.04$ & 0.304 & $49.0 \pm 4.56$ & 0.404 & $47.0 \pm 5.20$ & 0.547 & $51.5 \pm 8.86$ & 0.189 \\
\hline \multicolumn{10}{|l|}{ Urine $(\mathrm{ml})$} \\
\hline $\mathrm{HFrEF}^{\mathrm{b}}$ & $1172.3 \pm 759.7$ & $1408.4 \pm 697.9$ & 0.199 & $1319.1 \pm 701.3$ & 0.298 & $1263.4 \pm 606.5$ & 0.079 & $1051.0 \pm 676.3$ & 0.637 \\
\hline $\mathrm{HFpEF}{ }^{c}$ & $1431.4 \pm 1195.8$ & $1118.3 \pm 991.4$ & 0.273 & $1225.0 \pm 1198.9$ & 0.522 & $1092.3 \pm 818.5$ & 0.764 & $984.6 \pm 740.3$ & 0.744 \\
\hline \multicolumn{10}{|l|}{ pUF $^{\mathrm{a}}(\mathrm{ml})$} \\
\hline $\mathrm{HFrEF}^{\mathrm{b}}$ & $n a^{9}$ & $1180.6 \pm 1391.5$ & $n a^{9}$ & $1269.6 \pm 1566.5$ & 0.805 & $1020.3 \pm 952.1$ & 0.626 & $1306.8 \pm 1284.7$ & 0.870 \\
\hline $\mathrm{HFpEF}^{c}$ & $n a^{9}$ & $979.7 \pm 473.6$ & $n a^{9}$ & $982.6 \pm 442.4$ & 0.335 & $1140.6 \pm 552.6$ & 0.757 & $997.8 \pm 546.6$ & 0.359 \\
\hline \multicolumn{10}{|c|}{ Body Weight (kg) } \\
\hline HFrEF ${ }^{b}$ & $81.1 \pm 14.6$ & $76.7 \pm 15.2$ & $<0.001$ & $77.4 \pm 14.5$ & 0.002 & $76.7 \pm 14.3$ & 0.068 & $77.2 \pm 15.6$ & 0.003 \\
\hline $\mathrm{HFpEF}{ }^{c}$ & $86.9 \pm 15.8$ & $82.3 \pm 13.3$ & $<0.005$ & $80.8 \pm 11.0$ & 0.023 & $83.2 \pm 16.4$ & 0.046 & $83.1 \pm 15.9$ & 0.005 \\
\hline \multicolumn{10}{|c|}{$\begin{array}{l}\text { Data are presented as mean } \pm \text { SD } \\
\text { apUF (peritoneal ultrafiltration) } \\
\text { b } \mathrm{HFrEF} \text { (heart failure with reduced ejection fraction) } \\
\text { c } \mathrm{CHFpEF} \text { (heart failure with preserved ejection fraction) } \\
\text { d }{ }^{\mathrm{N} Y H A} \text { (New York Heart Association functional class) } \\
\text { eBP (blood pressure) } \\
\text { fEF (ejection fraction) } \\
\text { gna (not applicable) }\end{array}$} \\
\hline
\end{tabular}

HFrEF, there were no significant differences regarding pUF and urine volume. Body weight improved in both groups significantly (HFpEF $86.9 \pm 15.8 \mathrm{~kg}$ to $83.1 \pm 15.9$, $P=0.005$ and HFrEF $81.1 \pm 14.6 \mathrm{~kg}$ to $77.2 \pm 15.6, P=$ 0.003) (Fig. 1).

Regarding medication, use of MRA slightly decreased in HFrEF patients (37.4 to 32.0\%) and increased in HFpEF patients (35.1 to 47.4\%). Use of ACE inhibitors or ARBs decreased (HFrEF 54.2 to $39.7 \%$ vs. HFpEF 54.1 to $41.2 \%$ ) during first year after starting pUF. Meanwhile, use of beta blockers increased during this period (HFrEF 64.5 to $77.6 \%$ vs. HFpEF 56.8 to $65.4 \%$ ).

13 HFrEF patients (12.1\%) and 8 HFpEF patients (21.6\%) were treated with erythropoiesis stimulation agents (ESA) pre-pUF. This number increased to $18.6 \%$ in $\mathrm{HFpEF}$ and $37.5 \%$ in HFrEF at 12 months. In patients without ESAs or being on stable dosages of ESAs, we initially detected a significant increase of haemoglobin after 3 months (HFrEF from $11.3 \pm 1.74 \mathrm{mg} / \mathrm{dl}$ to $11.9 \pm$ $1.71 \mathrm{mg} / \mathrm{dl}, P=0.024$ and HFpEF from 10.81 .68 to $11.7 \pm 2.12, P=0.038$ ). Results improved but without significance at the end of the observation period of max. Seventy-two months (HFrEF $11.6 \pm 2.09 \mathrm{mg} / \mathrm{dl}, P=0.614$, HFpEF $11.2 \pm 2.40 \mathrm{mg} / \mathrm{dl}, P=0.105)$.

Focusing on heart failure entity, 12 months prior to pUF, no differences in number of hospitalizations $(P=$ $0.809)$ and days in hospital $(P=0.746)$ were detected among HFrEF and HFpEF. After initiation of pUF, total number $(2.88 \pm 1.62$ to $1.25 \pm 1.45, P=0.001)$ and days of hospitalizations $(40.4 \pm 31.7$ to $18.3 \pm 22.5, P=0.005)$ significantly decreased in HFpEF, but not in HFrEF patients $(2.79 \pm 1.70$ to $2.09 \pm 1.85, P=0.062 ; 38.5 \pm 27.5$ to $29.8 \pm 25.9, P=0.092$, respectively) (Fig. $2 \mathrm{a}$ and $\mathrm{b}$ ).

NYHA improved both in HFrEF (3.45 \pm 0.52 to $2.71 \pm$ $0.72, P<0.001)$ and in HFpEF $(3.19 \pm 0.61$ to $2.72 \pm$ $0.58, P<0.001$ ) (Fig. 3). 


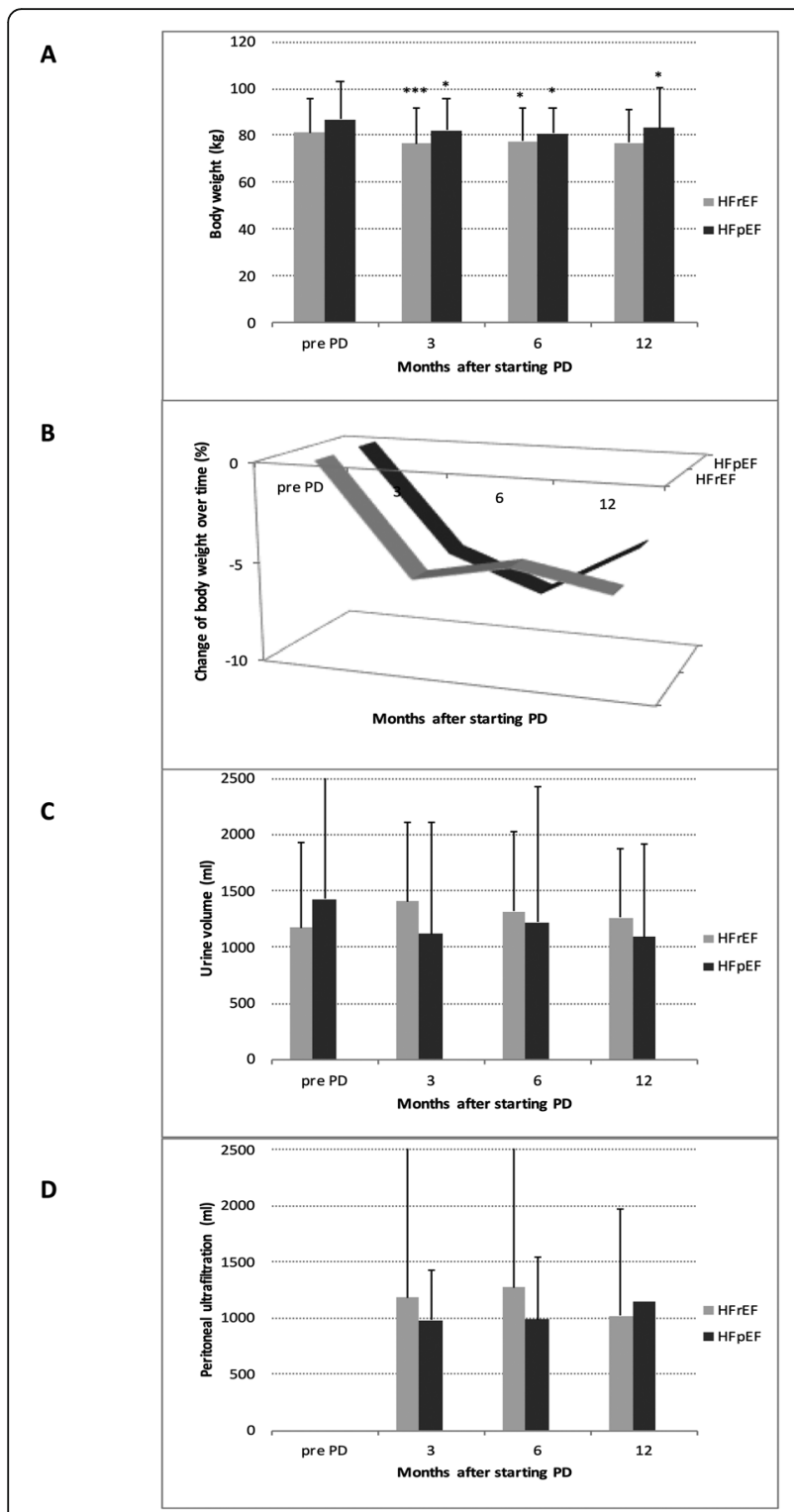

Fig. 1 Comparison of body weight (1a), relative change of body weight (1b) urine (1c) and peritoneal ultrafiltration (1d) after starting pUF in HFrEF and HFpEF. Not significant

HFrEF patients displayed significantly improved LVEF $(25.9 \pm 6.83 \%$ to $30.4 \pm 12.2 \%, P=0.046)$.

Average time until death was $439.0 \pm 471.9$ days in HFrEF and $392.9 \pm 373.2$ days in HFpEF. 4 HFrEF patients recompensated and $1 \mathrm{HFrEF}$ patient received kidney transplantation and therefore intermittently stopped pUF treatment. In addition, $7 \mathrm{HFrEF}$ and $5 \mathrm{HFpEF}$ patients changed medical centres for different reasons, and $38 \mathrm{HFrEF}$ and $12 \mathrm{HFpEF}$ were lost to follow-up. The registry data did not record complications systemically, but in our previous study, we demonstrated that nearly no cardiac decompensations occurred with pUF [32].
There was no significant mortality difference between HFpEF and HFrEF after starting pUF (Fig. 4) (first year $\log$-rank $=0.968$ ) and second year (Logrank $=0.830$ ). Similarly, there was no significant difference in mortality between ICMP and DCMP [33] (first year $\log$-rank=0.142 and second year $\log$ rank $=0.242$ respectively).

\section{Discussion}

This substudy confirms that pUF therapy potentially yields differential outcomes in HFpEF and HFrEF patients. Our findings demonstrate that particularly in HFpEF, but not so in HFrEF patients, pUF significantly reduced both number and days of hospitalization for all causes. The 30-day all-cause readmission rate is still $19 \%$ for HF patients [34] and the 1-year hospitalization rate runs up to $43.9 \%$ and $31.9 \%$, in HFrEF and HFpEF, respectively. From a medical as well as an economic point of view pUF may prove especially beneficial in HFpEF patients as it contributes to lower healthcare costs by reducing in-hospital days $[35,36]$. To date it is unclear what this finding might be related to, but one may speculate that the burden of cardiorenal interaction is even more pronounced in HFpEF as the incidence of pulmonary hypertension and renal dysfunction is slightly higher in this HF subgroup [37, 38].

Various studies on pUF described 1-year mortality rates between $18 \%$ and $44 \%$ with conventional treatment [39-41]. Wang et al. confirmed an increased mortality of HF patients with pUF treatment, which appeared even more pronounced in case of HFrEF [42]. In our study, however, we did not find any difference regarding 1 - and 2 year mortality or between ICMP and DCMP patients, which is most likely related to a highly variable comorbidity load between studies [30].

Our observations correspond with previous results, as NYHA classification improved significantly with pUF in all groups [43]. This symptomatic improvement translated only to significant changes in LVEF in HFrEF patients, which corresponds with findings of Courivaud et al. [41]. On first sight the impact of pUF on change/improvement of EF might depend on baseline EF. In former studies, however, it was demonstrated that LVEF does not add significant prognostic information in patients with advanced CKD [44]. Accordingly, the subgroup analysis of 1- and 2year mortality did not reveal any difference between DCMP and ICMP patients or between HFpEF and HFrEF patients as far as EF is concerned.

Independent from HF classification, an overall significant weight loss was documented. This finding has to be differentiated, as weight loss may on the one 


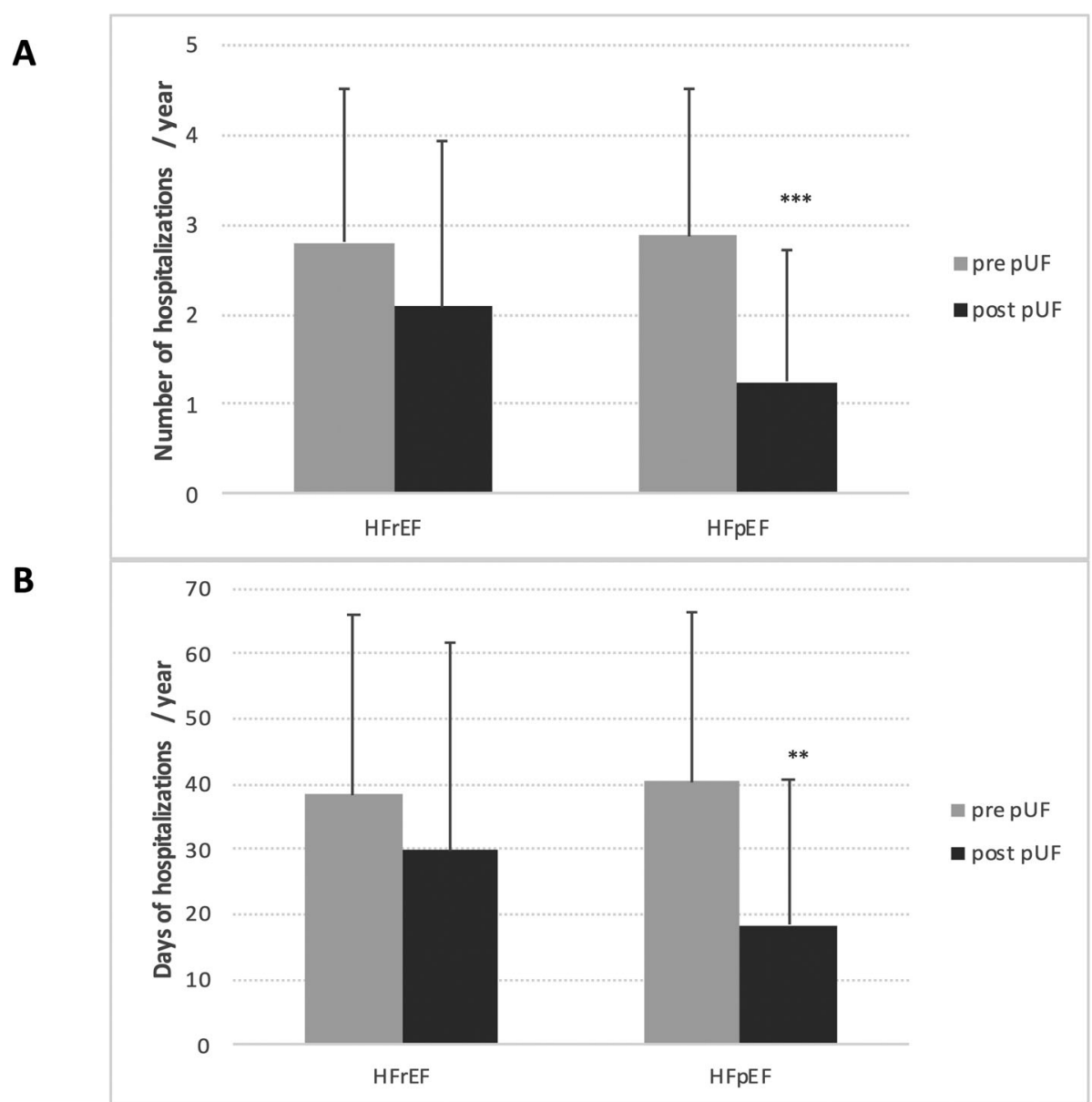

Fig. 2 Number of hospitalizations per year after starting pUF for patients with HFrEF and HFpEF (2a) and days of hospitalizations per year after starting pUF for patients with HFrEF and HFpEF (2b). ${ }^{* *} P<0.001$ and ${ }^{* *} P<0.01$

hand be seen as a marker for better volume management due to additional UF with remained urine output. On the other hand weight loss may be regarded as a marker for muscle loss and malnutrition, as PD patients lose several grams of protein per day via the dialysate. In this context it is important to note that albumin levels representing a strong predictor of survival remained within the normal range. We thus conclude that pUF therapy indeed leads to an improved volume management without triggering a significant wasting syndrome. The potential loss of proteins is obviously compensated by an improved resorption of nutritional components when the intraabdominal compartment is decongested as mentioned below.

Interestingly, a low BUN is associated with a significantly improved prognosis in HF patients [45-47]. In our cohort pUF treatment resulted in decreased BUN/ creatinine ratios (BCR), more pronounced in HFrEF patients. BCR can be regarded as a more powerful predictor of survival among HF patients with renal dysfunction than conventional renal function measures [48]. But contrary to literature, we observed in patients with HFrEF a lower BCR but no significant decrease in hospitalizations. This conflicting observation might be caused by the more pronounced elimination of BUN with pUF.

Moreover, we found weight loss to be accompanied by significantly lowered CRP and BUN levels in both groups. eGFR slightly decreased especially in HFpEF patients, potentially reflecting a sustained loss of oedema. As interstitial oedema in the intra-abdominal compartment is known to trigger both the translocation of LPS with ensuing secondary inflammation and to impede resorption of nutritional compounds, it can cause profound cachexia [49]. So not only theoretically, pUF allows an intracorporeal, gentle and continuous UF to relieve the reno-venous and intra-abdominal pressure overload while draining ascites and interstitial oedema [50, 51]. This potentially aids to stabilize the remaining glomerular filtration rate and helps to decrease inflammation. These findings 


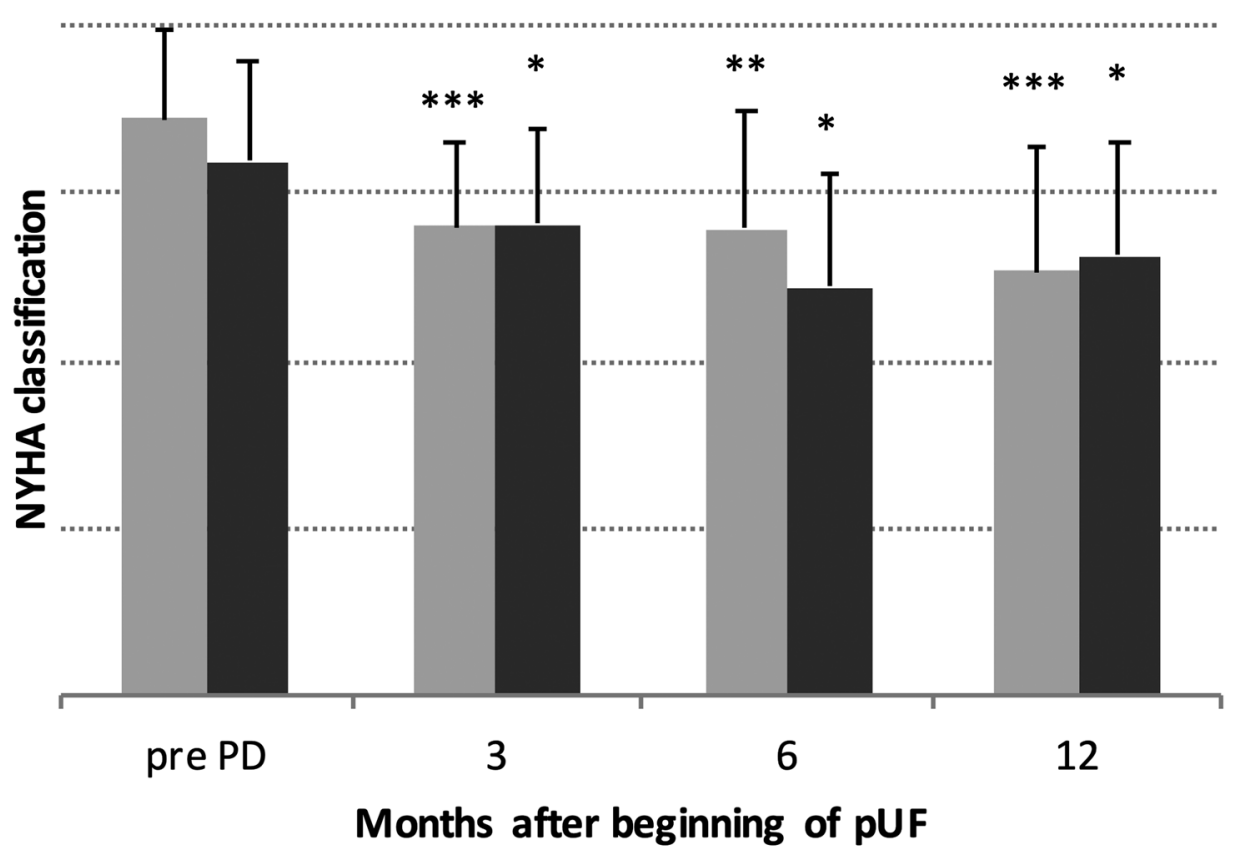

Fig. 3 NYHA classification after starting pUF in patients with HFrEF and HFpEF. ${ }^{* *} P<0.001,{ }^{* *} P<0.01$ and ${ }^{*} P<0.05$

might be one of the main advantages as compared to extracorporeal haemofiltration strategies, where rapid intravascular fluid removal causes sympathetic counteractivation with a deterioration of renal function and where intraabdominal congestion is not influenced.

Despite the positive combination of reduced dyspnoea (reflected by improved NYHA classification) and increased weight loss, serial NTproBNP values remained unaffected throughout the study. Looking at the withinperson variation instead of the rather large betweenperson variation [52], however, revealed a different picture: The relative NTproBNP levels decreased in both groups, indicating the positive effects of pUF treatment in CHF, although this effect was more pronounced in HFpEF patients.

Another important aspect is that medical HF therapy in patients with CKD is frequently limited by hyperkalaemia, so patients are less likely to receive effective dosages of ACE inhibitors or ARBs [53]. Interestingly, patients with pUF often display a mild hypokalaemia, which may represent an additional advantage over haemodialysis as it offers the chance to reach a dosage of RAAS blockers or MRAs that would accord to the guidelines [22]. In our patient cohort, initially an adequate medical HF therapy was possible only in $35-54 \%$ of patients. Use of ACE/ ARBs decreased but use of MRAs increased in HFpEF patients with pUF. Use of beta blockers increased in both groups. Further studies are needed to give clarification about a potential benefit of higher dosage of MRA and beta blockers in this special patient cohort.

Finally, some limitations should be noted. The study comprises a relatively small patient cohort, while cardiorenal patients were included from 18 different centres. This all-comers population may thus have resulted in a highly heterogeneous collective that does not allow the exclusion of potential biases. Heterogeneity, however, is a problem always inherent to the HF syndrome which is driven by the complex situation of multiple comorbidities. In our recent publication [29] we therefore chose to analyse the Charlson Comorbidity Score that revealed a halving of the expected mortality. Moreover, the reduced hospital admissions may have been counterbalanced by the complexity of pUF therapy, which should have been controlled for by a standardized quality of life assessment. Our previous study, however, invalidates this objection by demonstrating an improved quality of life with pUF [32]. Finally, the fact that pUF patients received a rather close monitoring might have resulted in an improved outcome on its own.

\section{Conclusion}

To conclude, in our study all congestive HF patients clinically improved. While HFpEF patients might in particular benefit the most with respect to hospitalization, 


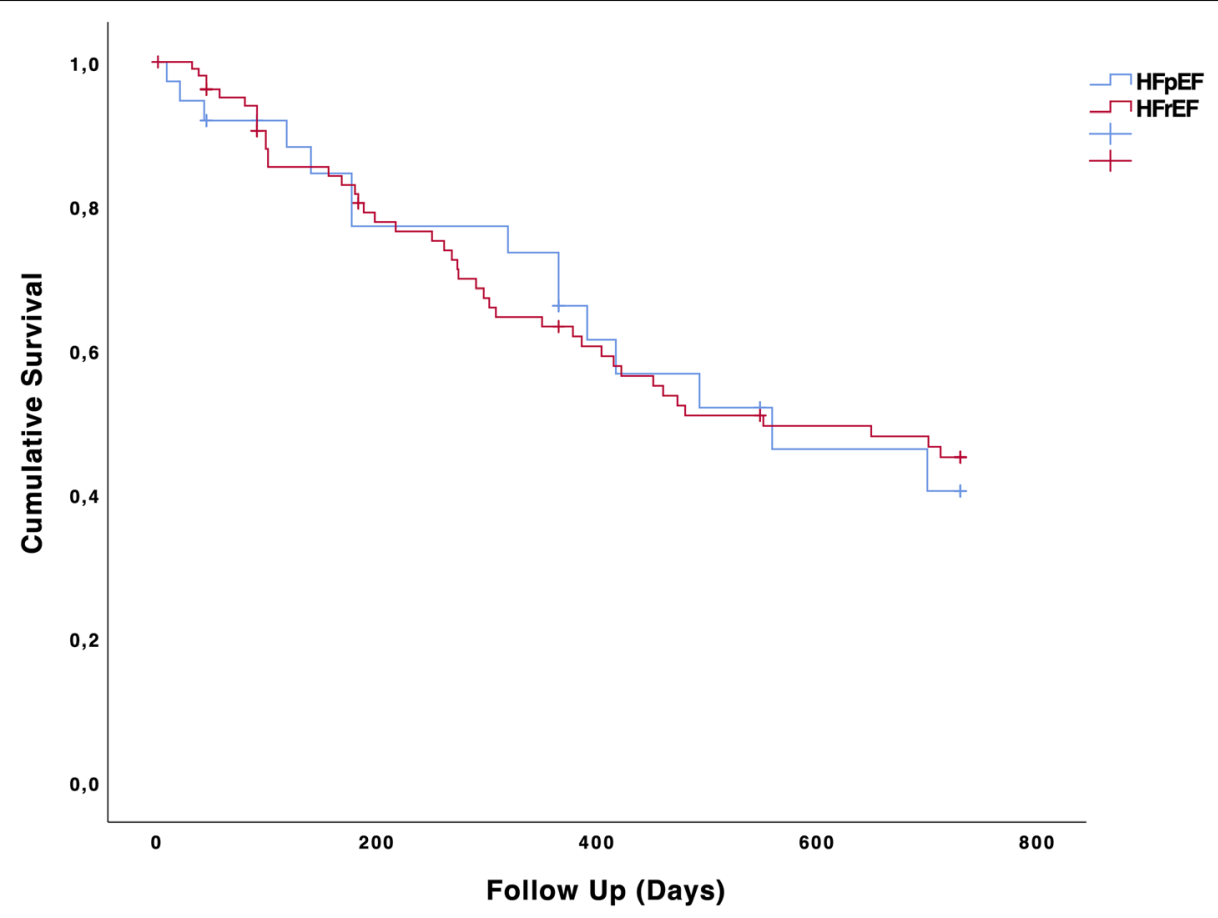

Fig. 4 Kaplan-Meier survival curve. Cumulative survival of HFpEF and HFrEF 2 years after starting pUF therapy

HFrEF patients experienced an improvement concerning EF. This study thus warrants larger controlled studies in order to elaborate the differential effects of pUF as an adjunct palliative therapy in end stage HF. With regard to HFpEF patients it may be especially rewarding to gain more insight concerning the specific cardio-pulmo-renal interactions as this clinical entity still is in search for evidence based therapeutic approach.

\section{Abbreviations}

ACE: Angiotensin converting enzyme; ARB: Angiotensin II receptor blocker; BUN: Blood urea nitrogen; BCR: BUN Creatinine ratio; CAPD: Continuous ambulatory peritoneal dialysis; CKD: Chronic kidney disease; DGfN: Deutsche Gesellschaft für Nephrologie; ESC: European Society of Cardiology; CRP: C Reactive protein; DCMP: Dilated cardiomyopathy; EF: Ejection fraction; eGFR: estimated Glomerular Filtration Rate; HF: Heart failure; HFpEF: Heart failure with preserved ejection fraction; HFrEF: Heart failure with reduced ejection fraction; ICMP: Ischemic cardiomyopathy; LVEF: Left ventricular ejection fraction; MDRD: Modification of diet in renal disease; MRA: Mineralocorticoid receptor antagonist; NYHA: New York Heart Association; PD: Peritoneal dialysis; pUF: peritoneal Ultrafiltration; RAAS: Renin angiotensin aldosterone system; UF: Ultrafiltration

\section{Acknowledgements}

\section{Data collection:}

Bommersbach, B., MD, Clinic Memmingen, Memmingen, Germany.

Brockmann, C., MD, Medical Center, Bad Bevensen, Germany.

Bunia, J., MD, Practice for Dialysis, Iserlohn, Germany.

Dose, U., MD, Dialysis Center, Siegburg, Germany.

Frankenstein, L, MD, PhD, University Hospital of Heidelberg, Germany. Hintzen-Kruse, C., MD, Clinic Chemnitz Nephrology, Chemnitz, Germany. Kreusser, M.M., MD, University Hospital of Heidelberg, Germany. Kihm, L.P., MD, University Hospital of Heidelberg, Germany. Ludwig, S., MD, Werner-Forßmann Clinic, Eberswalde, Germany. Martin, H., MD, Practice for Dialysis, Germany.

Meyer, K., MD, Heart and Vascular Center, Bad Bevensen, Germany.
Mündle, M., MD, State Hospital Feldkirch, Feldkirch, Austria. Remppis, A., MD, Heart and Vascular Center, Bad Bevensen, Germany. Schillinger-Pokorny, E., MD, Center for Nephrology, Offenburg, Germany. Tönges, J., MD, Networked Hospitals Bernkastel-Wittlich, Wittlich, Germany. Tönne, G., MD, Practice for Dialysis, Warendorf, Germany.

Toepfer, M., MD, Dialysis Center Murnau, Weilheim, Garmisch, Germany. Poludniak, I., Center for Nephrology, Mettmann, Velbert, Hilden, Haa, Germany.

Reinhard, W., MD, Dialysis Center, Papenburg, Germany. Schwenger V., MD, Katharinenhospital, Stuttgart, Germany. Wanninger, R., MD, Clinic Braunschweig, Braunschweig, Germany. Wolf, L., MD, Center for Nephrology, Villingen-Schwenningen, Germany. Von Appen, K., MD, Practice for Nephrology, Lohbrügge, Germany. Zeier, M., MD, University Hospital of Heidelberg, Germany.

Data pseudonymisation:

Gnädig, B., Networked Hospitals Bernkastel-Wittlich, Wittlich, Germany. Statistical analysis:

Grossekettler, W.R.

\section{Authors' contributions}

L.F., M.M.K., H.A.K., C.B., R.W., L.P.K., M.Z., A.R. and V.S. acquired patients and generated the data. L.G., A. R, V.S. and B.S. interpreted the data set. L.G., B.S. and L.F. helped with the statistical analysis. B.S., M.M.K, H.A.K., A.R. and V.S. performed proofreading of the manuscript. All authors read and approved the final manuscript.

\section{Funding}

This work was financially supported by Deutsche Gesellschaft für Nephrologie e.V. (DGfN). The DGfN helped to compile the register structure. The DGFN was not involved data interpretation or in writing the manuscript.

\section{Availability of data and materials}

The data that support the findings of this study are available from Gnädig. B. but restrictions apply to the availability of these data, which were used under license for the current study, and so are not publicly available. Data are however available from the authors upon reasonable request and with permission of DGfN and Schwenger $V$. as well as Remppis A. 


\section{Ethics approval and consent to participate}

All patients provided written informed consent. The study was approved by the Ethics Committee of the Medical Faculty of Heidelberg (reference number S-106/2011).

\section{Consent for publication}

Not applicable.

\section{Competing interests}

C.B., L.F., L.G., L.P.K., M.M.K., K.M., A.R., V.S., and M.Z. declare that they have no conflicts of interest. B.S. reports a conference/travel grant from St Jude Medical-HeartWare and a travel grant as well as personal fees from Berlin Heart GmbH, outside the submitted work. R.W. has received personal fees from Baxter Germany and Fresenius Germany. H.A.K. reports personal fees from AstraZeneca, personal fees from Daiichi Sankyo, personal fees from NovoNordisk, personal fees from Novartis, personal fees from Roche Diagnostics, personal fees from Bayer Vital, outside the submitted work.

\section{Author details}

'Department of Internal Medicine III, Cardiology, Angiology and Pulmonology, University Hospital of Heidelberg, Im Neuenheimer Feld 410, 69120 Heidelberg, Germany. ${ }^{2}$ Clinic for Cardiac Surgery, University Hospital of Heidelberg, Heidelberg, Germany. ${ }^{3}$ Clinic for Cardiology, Heart and Vascular Center, Bad Bevensen, Germany. ${ }^{4}$ Department of Nephrology, Medical Center, Bad Bevensen, Germany. ${ }^{5}$ Department of Nephrology, Clinic Braunschweig, Braunschweig, Germany. ${ }^{6}$ Department of Internal Medicine I, Endocrinology and Nephrology, University Hospital of Heidelberg, Heidelberg, Germany. 'Department of Kidney-, Blood Pressure- and Autoimmune Diseases, Katharinenhospital, Klinikum Stuttgart, Stuttgart, Germany.

Received: 13 September 2019 Accepted: 20 March 2020

Published online: 14 May 2020

\section{References}

1. McMurray JJ, Adamopoulos S, Anker SD, Auricchio A, Bohm M, Dickstein K, Falk V, Filippatos G, Fonseca C, Gomez-Sanchez MA, Jaarsma T, Kober L, Lip GY, Maggioni AP, Parkhomenko A, Pieske BM, Popescu BA, Ronnevik PK, Rutten FH, Schwitter J, Seferovic P, Stepinska J, Trindade PT, Voors AA, Zannad F, Zeiher A. ESC Guidelines for the diagnosis and treatment of acute and chronic heart failure 2012: The task force for the diagnosis and treatment of acute and chronic heart failure 2012 of the European Society of Cardiology. Developed in collaboration with the Heart Failure Association (HFA) of the ESC. Eur Heart J. 2012;33:1787-847.

2. Braunwald E. Heart failure. JACC Heart Fail 2013; 1: 1-20.3. Maggioni AP, Dahlstrom U, Filippatos G et al. EURObservational research Programme: regional differences and 1-year follow-up results of the heart failure pilot survey (ESC-HF pilot). Eur J Heart Fail 2013; 15: 808-817.

3. Crespo-Leiro MG, Anker SD, Maggioni AP, et al. European Society of Cardiology Heart Failure Long-Term Registry (ESC-HF-LT): 1-year follow-up outcomes and differences across regions. Eur J Heart Fail. 2016;18:613-25.

4. Donkor A, Cleland J, McDonagh T, Hardman S. National Heart Failure Audit. 2016; 11.07.2016.

5. Ponikowski P, Voors AA, Anker SD, et al. 2016 ESC guidelines for the diagnosis and treatment of acute and chronic heart failure: the task force for the diagnosis and treatment of acute and chronic heart failure of the European Society of Cardiology (ESC) developed with the special contribution of the heart failure association (HFA) of the ESC. Eur Heart J. 2016:37:2129-200.

6. Yancy CW, Jessup M, Bozkurt B, et al. 2013 ACCF/AHA guideline for the management of heart failure: executive summary: a report of the American College of Cardiology Foundation/American Heart Association task force on practice guidelines. Circulation. 2013;128:1810-52.

7. KDOQI clinical practice guidelines for chronic kidney disease: evaluation, classification, and stratification. Am J Kidney Dis. 2002; 39:S1-266.

8. McMurray JJ. Chronic kidney disease in patients with cardiac disease: a review of evidence-based treatment. Kidney Int. 2005;68:1419-26.

9. Hillege HL, Girbes AR, de Kam PJ, Boomsma F, de Zeeuw D, Charlesworth A, Hampton JR, van Veldhuisen DJ. Renal function, neurohormonal activation, and survival in patients with chronic heart failure. Circulation. 2000;102:203-10.
10. McAlister FA, Ezekowitz J, Tonelli M. Armstrong PW (2004) renal insufficiency and heart failure: prognostic and therapeutic implications from a prospective cohort study. Circulation. 2004;109:1004-9.

11. van Deursen VM, Urso R, Laroche C, Damman K, Dahlström U, Tavazzi L, Maggioni AP, Adriaan A. Voors1 Co-morbidities in patients with heart failure: an analysis of the European Heart Failure PilotSurvey. Eur J Heart Fail. 2014; 16:103-11.

12. Heywood JT, Fonarow GC, Costanzo MR, Mathur VS, Wigneswaran JR, Wynne J. High prevalence of renal dysfunction and its impact on outcome in 118,465 patients hospitalized with acute decompensated heart failure: a report from the ADHERE database. J Card Fail. 2007;13:422-30.

13. Mullens W, Abrahams Z, Francis GS, Sokos G, Taylor DO, Starling RC, Young $J B$, Tang WH. Importance of venous congestion for worsening of renal function in advanced decompensated heart failure. J Am Coll Cardiol. 2009; 53:589-96.

14. Damman $K$, van Deursen VM, Navis G, Voors AA, van Veldhuisen DJ, Hillege $\mathrm{HL}$. Increased central venous pressure is associated with impaired renal function and mortality in a broad spectrum of patients with cardiovascular disease. J Am Coll Cardiol. 2009;53:582-8.

15. Bock JS, Gottlieb SS. Cardiorenal syndrome: new perspectives. Circulation. 2010;121:2592-600.

16. Testani JM, Khera AV, St John Sutton MG, Keane MG, Wiegers SE, Shannon $\mathrm{RP}$, Kirkpatrick JN. Effect of right ventricular function and venous congestion on cardiorenal interactions during the treatment of decompensated heart failure. Am J Cardiol. 2010;105:511-6.

17. Shamseddin MK, Parfrey PS. Mechanisms of the cardiorenal syndromes. Nat Rev Nephrol. 2009;5:641-9.

18. Dini FL, Demmer RT, Simioniuc A, Morrone D, Donati F, Guarini G, Orsini E, Caravelli P, Marzilli M, Colombo PC. Right ventricular dysfunction is associated with chronic kidney disease and predicts survival in patients with chronic systolic heart failure. Eur J Heart Fail. 2012;14:287-94.

19. Doty JM, Saggi BH, Blocher CR, Fakhry I, Gehr T, Sica D, Sugerman HJ. Effects of increased renal parenchymal pressure on renal function. J Trauma. 2000:48:874-7.

20. Ronco C, Haapio M, House AA, Anavekar N, Bellomo R. Cardiorenal syndrome. J Am Coll Cardiol. 2008:52:1527-39.

21. Hunt SA, Abraham WT, Chin MH, Feldman AM, Francis GS, Ganiats TG, Jessup M, Konstam MA, Mancini DM, Michl K, Oates JA, Rahko PS, Silver MA, Stevenson LW, Yancy CW. 2009 Focused update incorporated into the ACC/ AHA 2005 Guidelines for the Diagnosis and Management of Heart Failure in Adults A Report of the American College of Cardiology Foundation/ American Heart Association Task Force on Practice Guidelines Developed in Collaboration With the International Society for Heart and Lung Transplantation. J Am Coll Cardiol. 2009;53:1-90.

22. Ronco C, McCullough P, Anker SD, Anand I, Aspromonte N, Bagshaw SM, Bellomo R, Berl T, Bobek I, Cruz DN, Daliento L, Davenport A, Haapio M, Hillege H, AA H, Katz N, Maisel A, Mankad S, Zanco P, Mebazaa A, Palazzuoli A, Ronco F, Shaw A, Sheinfeld G, Soni S, Vescovo G, Zamperetti N, Ponikowski P. Cardio-renal syndromes: report from the consensus conference of the acute dialysis quality initiative. Eur Heart J. 2010;31:703-11.

23. Bart BA, Goldsmith SR, Lee KL, Givertz MM, O'Connor CM, Bull DA, Redfield MM, Deswal A, Rouleau JL, LeWinter MM, Ofili EO, Stevenson LW, Semigran MJ, Felker GM, Chen HH, Hernandez AF, Anstrom KJ, McNulty SE, Velazquez EJ, Ibarra JC, Mascette AM, Braunwald E. Ultrafiltration in decompensated heart failure with cardiorenal syndrome. N Engl J Med. 2012;367:2296-304.

24. Rogers HL, Marshall J, Bock J, Dowling TC, Feller E, Robinson S, Gottlieb SS. A randomized, controlled trial of the renal effects of ultrafiltration as compared to furosemide in patients with acute decompensated heart failure. J Card Fail. 2008;14:1-5.

25. Costanzo MR, Negoianu D, Fonarow GC, Jaski BE, Bart BA, Heywood JT, Nabut JL, Schollmeyer MP. Rationale and design of the Aquapheresis versus intravenous diuretics and hospitalization for heart failure (AVOID-HF) trial. Am Heart J. 2015;170:471-82.

26. Costanzo MR, Guglin ME, Saltzberg MT, Jessup ML, Bart BA, Teerlink JR, Jaski BE, Fang JC, Feller ED, Haas GJ, Anderson AS, Schollmeyer MP, Sobotka PA. Ultrafiltration versus intravenous diuretics for patients hospitalized for acute decompensated heart failure. J Am Coll Cardiol. 2007;49:675-83.

27. Bart BA, Boyle A, Bank AJ, Anand I, Olivari MT, Kraemer M, Mackedanz S, Sobotka PA, Schollmeyer M, Goldsmith SR. Ultrafiltration versus usual care for hospitalized patients with heart failure: the relief for acutely fluid- 
overloaded patients with decompensated congestive heart failure (RAPIDCHF) trial. J Am Coll Cardiol. 2005:46:2043-6.

28. Grossekettler L, Schmack B, Meyer M, Brockmann C, Wanninger R, Kreusser MM, Frankenstein L, Kihm LP, Zeier M, Katus HA, Remppis A, Schwenger V. Peritoneal dialysis as therapeutic option in heart failure patients. 23 ESC Heart Fail. 2019:6:271-9.

29. Lu R, Mucino-Bermejo MJ, Ribeiro LC, Tonini E, Estremadoyro C, Samoni S, Sharma A, Zaragoza Galvan Jde J, Crepaldi C, Brendolan A, Ni Z, Rosner MH, Ronco C. Peritoneal dialysis in patients with refractory congestive heart failure: a systematic review. Cardiorenal Med. 2015;5:145-56.

30. Schwenger $V$, Remppis BA, Westenfeld $R$, Weinreich $T$, Brunkhorst $R$, Schieren G, Krumme B, Haller H, Schmieder R, Schlieper G, Frye B, Hoppe UC, Hoyer J, Keller T, Blumenstein M, Schunkert H, Mahfoud F, Rump LC. Dialysis and ultrafiltration therapy in patients with cardio-renal syndrome: recommendations of the working group "heart-kidney" of the German cardiac society and the German Society of Nephrology. Dtsch Med Wochenschr. 2014;139:1-8.

31. Frohlich H, Katus HA, Tager T, Lossnitzer N, Grossekettler L, Kihm L, Zeier M, Remppis A, Frankenstein L, Schwenger V. Peritoneal ultrafiltration in endstage chronic heart failure. Clin Kidney J. 2015;8:219-25.

32. Richardson P, McKenna W, Bristow M, et al. Report of the 1995 World Health Organization/International Society and Federation of Cardiology Task Force on the Definition and Classification of cardiomyopathies. Circulation. 1996; 93:841.

33. Bergethon KE, Ju C, DeVore AD, Hardy NC, Fonarow GC, Yancy CW, Heidenreich PA, Bhatt DL, Peterson ED, Hernandez AF. Trends in 30-Day Readmission Rates for Patients Hospitalized With Heart Failure: Findings From the Get With The Guidelines-Heart Failure Registry. Circ Heart Fail. 2016;9:1-8.

34. Maggioni AP, Dahlstrom U, Filippatos G, et al. EURObservational research Programme: regional differences and 1-year follow-up results of the heart failure pilot survey (ESC-HF pilot). Eur J Heart Fail. 2013;15:808-17.

35. Sens F, Schott-Pethelaz AM, Labeeuw M, Colin C, Villar E. Survival advantage of hemodialysis relative to peritoneal dialysis in patients with end-stage renal disease and congestive heart failure. Kidney Int. 2010;80:970-7.

36. Rosenkranz S, Gibbs JSR, Wachter R, De Marco T, Vonk-Noodregraaf A, Vachiéry JL. Left ventricular heart failure and pulmonary hypertension. Eur Heart J. 2016:37:942-54.

37. Smith DH, Thorp ML, Gurwitz JH, et al. Chronic kidney disease and outcomes in heart failure with preserved versus reduced ejection fraction: the cardiovascular research network PRESERVE study. Circ Cardiovasc Qual Outcomes. 2013;6:333-42.

38. Sanchez JE, Ortega T, Rodriguez C, Diaz-Molina B, Martin M, Garcia-Cueto C, Vidau P, Gago E, Ortega F. Efficacy of peritoneal ultrafiltration in the treatment of refractory congestive heart failure. Nephrol Dial Transplant. 2010;25:605-10.

39. Koch M, Haastert B, Kohnle M, Rump LC, Kelm M, Trapp R, Aker S. Peritoneal dialysis relieves clinical symptoms and is well tolerated in patients with refractory heart failure and chronic kidney disease. Eur J Heart Fail. 2012;14: 530-9.

40. Courivaud C, Kazory A, Crepin T, Azar R, Bresson-Vautrin C, Chalopin JM, Ducloux D. Peritoneal dialysis reduces the number of hospitalization days in heart failure patients refractory to diuretics. Perit Dial Int. 2014;34(1):100-8.

41. Wang AY, Wang M, Lam CW, Chan IH, Lui SF, Sanderson JE. Heart failure with preserved or reduced ejection fraction in patients treated with peritoneal dialysis. Am J Kidney Dis. 2013;61:975-83:10.

42. Cnossen TT, Kooman JP, Krepel HP, Konings CJ, Uszko-Lencer NH, Leunissen KM, van der Sande FM. Prospective study on clinical effects of renal replacement therapy in treatment-resistant congestive heart failure. Nephrol Dial Transplant. 2012;27:2794-9.

43. Stabton T, Leano R, Marwick TH. Prediction of all-cause mortality from global longitudinal speckle strain. Comparison with ejection fraction and wall motion scoring. Circ cardiovasc Imaging. 2009;2:356-64.

44. Damman K, Testani JM. The kidney in heart failure: an update. Eur Heart J. 2015;36:1437-44.

45. Heywood JT, Elatre W, Pai RG, Fabbri S, Huiskes B. Simple clinical criteria to determine the prognosis of heart failure. J Cardiovasc Pharmacol Ther. 2005; 10:173-80.

46. Testani JM, Cappola TP, Brensinger CM, Shannon RP, Kimmel SE. Interaction between loop diuretic-associated mortality and blood urea nitrogen concentration in chronic heart failure. J Am Coll Cardiol. 2011;58:375-82.
47. Takaya Y, Yoshihara F, Yokoyama H, Kanzaki H, Kitakaze M, Goto Y, Anzai T, Yasuda S, Ogawa H, Kawano Y. Risk stratification of acute kidney injury using the blood urea nitrogen/creatinine ratio in patients with acute decompensated heart failure. Circ J. 2015;79:1520-5.

48. Cicoira M, Anker SD, Ronco C. Cardio-renal cachexia syndromes (CRCS): pathophysiological foundations of a vicious pathological circle. J Cachexia Sarcopenia Muscle. 2012;2:135-42.

49. Damman K, Solomon SD, Pfeffer MA, Swedberg K, Yusuf S, Young JB, Rouleau JL, Granger CB, McMurray JJ. Worsening renal function and outcome in heart failure patients with reduced and preserved ejection fraction and the impact of angiotensin receptor blocker treatment: data from the CHARM-study programme. Eur J Heart Fail. 2016;18:1508-17.

50. Mullens W, Nijst P. Cardiac output and renal dysfunction: definitely more than impaired flow. J Am Coll Cardiol. 2016;67:2209-12.

51. Fahim MA, Hayen A, Horvath AR, Dimeski G, Coburn A, Johnson DW, Hawley CM, Campbell SB, Craig JC. N-terminal pro-B-type natriuretic peptide variability in stable dialysis patients. Clin J Am Soc Nephrol. 2015;10:620-9.

52. Berger AK, Duval S, Manske C, Vazquez G, Barber C, Miller L, Luepker RV. Angiotensin-converting enzyme inhibitors and angiotensin receptor blockers in patients with congestive heart failure and chronic kidney disease. Am Heart J. 2007;153:1064-73.

\section{Publisher's Note}

Springer Nature remains neutral with regard to jurisdictional claims in published maps and institutional affiliations.

\section{Ready to submit your research? Choose BMC and benefit from:}

- fast, convenient online submission

- thorough peer review by experienced researchers in your field

- rapid publication on acceptance

- support for research data, including large and complex data types

- gold Open Access which fosters wider collaboration and increased citations

- maximum visibility for your research: over $100 \mathrm{M}$ website views per year

At BMC, research is always in progress.

Learn more biomedcentral.com/submissions 